\title{
If Congress Is So Dysfunctional, Why Is Its Staff So Busy? A Congressional Fellow's Perspective
}

\author{
Jeremy Gelman, University Of Nevada, Reno
}

\section{All views and opinions expressed in this article are those of the author.}

$\mathrm{T}$ he seven months I spent working in the US Senate as an APSA congressional fellow were characterized by two seemingly contradictory trends: the Senate accomplished very little and its staff was unusually busy. Indeed, from January through July 2017, by conventional measures the Senate was unproductive. ${ }^{1}$ Even with unified control of government, the Republican majority's main accomplishments consisted of confirming Neil Gorsuch to the Supreme Court, which required doing away with the 6o-vote threshold for Supreme Court nominees, passing 14 Congressional Review Act resolutions, which could not be filibustered, and enacting a bipartisan sanctions bill. In responding to the chamber's meager accomplishments, Senator John McCain (R-AZ) took to the floor and admonished his colleagues that they were "getting nothing done."

Other activities, such as confirming administration nominees, did not substitute for this legislative inaction. President Trump nominated fewer executive branch officials than his predecessors. Confirmations lagged for a variety reasons, including Democratic obstruction and inefficient vetting by the White House (Uhrmacher and Schaul 2017). In fact, for the final two weeks of my fellowship, the Senate ground to a near halt, as the ill-fated bill to repeal and replace parts of Obamacare dominated the floor agenda.

Yet, behind the scenes a strange contradiction played out. While the Senate was doing very little, staffers were busier than ever. A common, bipartisan refrain among staff members, some of whom had been on

Jeremy Gelman (PhD, University of Michigan) is assistant professor of political science at the University of Nevada, Reno. His research focuses on the United States Congress, presidency, and interest groups. During the 2016-2017 academic year, Gelman was an APSA congressional fellow and worked in the office of Senator Jack Reed (D-RI). He can becontacted at jgelman@unr.edu.
Capitol Hill for years, was that days felt like weeks, and weeks felt like months.

If the Senate was not passing important legislation or confirming nominees, what accounts for this heavy workload? In my view, three main factors contributed to this phenomenon: 1) an increase in messaging politics; 2 ) the unprecedented nature of the Trump administration; and 3 ) the difficulty of navigating a polarized Congress.

\section{MESSAGING ALL THE TIME}

The 115th Congress's first seven months was dominated by what congressional scholars have come to dub as messaging politics. Defined as a series of activities that make a political point, but will not change public policy, messaging predominated during my time as a fellow. Lee (2016) argues that in unified government, the minority party relies on messaging strategies as a way to force the majority party to take unpopular positions and tarnish their reputation. Additionally, research I have conducted indicates that messaging is used to generate political support from a party's allied interest groups (Gelman 2017).

In line with these arguments, a hallmark of the early portion of the 115th Congress was Democrats vigorously and constantly engaging in messaging politics. A flood of constituent communication, from individuals as well as local interest group chapters, drove this political strategy. Indeed, our office was inundated with messages and meeting requests from long-standing interest groups as well as new liberal advocacy organizations, such as Indivisible. In response to this sustained and intense constituent pressure, senators increasingly engaged in messaging politics.

For example, when Republicans attempted to repeal the Affordable Care Act, Democrats employed a variety of tactics aimed at scoring political points at the Republicans' expense. As the Senate inched closer to a repeal vote, Democrats used their procedural power to slow routine legislative business in an effort to draw more attention to the issue (Kaplan and Pear 2017). During Senate vote-a-ramas, the procedural requirement that allows unlimited amendments during a budget resolution debate, each party coordinated to ensure their most electorally vulnerable members offered the most politically-potent amendments that were sure to fail. As the final ACA repeal vote approached, Senator Heller (R-NV), the most electorally vulnerable Republican senator, was allowed to offer a final messaging amendment while Senator Donnelly (D-IN), one of the most electorally vulnerable Democrats, offered the motion to recommit.

At the individual level, Senators and their staffs constantly sought new ways to engage in partisan bickering. For example, Democratic Senators sent dozens of oversight letters, which are letters to agencies requesting an explanation for an action, knowing the executive branch would ignore their requests. Democrats used these letters as evidence that President Trump and his appointees were abusing their power and were not accountable to Congress.

From a time and resources perspective, these activities are not trivial. Staff are constantly strategizing which messaging opportunities will be most effective, which colleagues the senator should work with on that topic, what is the best way to frame the issue, and how to best publicize the senator's activity back home. A single messaging oversight letter, for example, involves a series of meetings that include members of the legislative staff, the communications staff, the chief of staff, and the senator. The legislative staff, after consulting with other offices the senator is working with, drafts the letter. The legislative director, chief of staff, and senator approve the letter. The communications staff writes a press release, schedules TV appearances, and contacts local press to ensure they pick up the story. Only then is the letter sent to the agency. This sort of activity happens multiple times a week.

It is hard to overstate the omnipresence of messaging politics and how time and resource demanding these activities are. In this vein, Lee $(2016,113-116)$ argues the substantial increase in communications staff employed by party leadership in Congress 
is evidence of an increasing emphasis on partisan messaging. However, at least in the 115th Congress, messaging has become so ubiquitous that legislative staffers play an essential role in this process. In addition to their more traditional jobs of researching policy issues, taking meetings, and briefing their members, policy-oriented staff draft messaging bills, amendments, and oversight letters as well as staff their member through activities that are only intended to make a political point. When increased messaging responsibilities are combined with more traditional tasks, it is no wonder staff is busier than ever.

\section{THE UNPRECEDENTED TRUMP PRESIDENCY}

In addition to messaging politics, the election of Donald Trump has created a more hectic pace on Capitol Hill. While it is common to hear how President Trump has upset the rhythms of Washington, DC, one concrete way the administration changed Capitol Hill is by adding to the workload of congressional staff. In particular, the Trump administration's propensity to generate unprecedented political situations created a near daily crush of unexpected deadlines for staffers.

A prime example of such a situation was the firing of FBI Director James Comey on May 9, 2017 and the subsequent appointment of Robert Mueller as special counsel for the Russia investigation on May 17, 2017. During this nine-day period, senators were inundated with questions from both the press and constituents about their stance on Comey's firing. Consequently, senators relied on their staffs to answer a myriad of questions about when presidents have fired national security or law enforcement officials in the past, why Congress let the special prosecutor law lapse in 1999, what was the senator's previous position on special counsels, what would constitute obstruction of justice, and the list goes on. All of this research was used to help develop a clear, concrete stance based on how each senator viewed Comey's firing and the subsequent appointment of Mueller.

Again, this allocation of resources is not trivial. While Comey's firing and Mueller's appointment dominated the news, the normal rhythms of government continued. The relevant legislative and communications staffers simply added to this issue, and various other Trump-specific controversies, to their portfolios. From my vantage point, none of these events replaced staffers' other work; it only added more to their plates.
NAVIGATING A POLARIZED AND PARTISAN CONGRESS

A final factor that increases staffs' workload is polarization and partisanship. Quite simply, it takes a lot of work to work across the aisle in the contemporary Congress. Perhaps the most illustrative example was my and a fellow staffer's experience trying to find cosponsors for a bill the senator planned to introduce. Our goal was to find at least two fellow committee members, one Democrat and one Republican, to cosponsor the legislation.

Getting our copartisan senator to sign onto the bill was straightforward. We called the relevant staff member, with whom we had a good working relationship. He told us he would talk to his boss, the senator, and by the next day our bill had its first cosponsor. Finding a cosponsor from the other party took over a month. We approached multiple senators on the committee, but most declined. We solicited feedback from interest groups regarding who might be interested in becoming a cosponsor. I pestered staffers who never responded to my emails. Eventually, one office expressed interest. After a half dozen follow-up emails, two phone calls, a conversation between the senators on the floor, and a conversation between the offices' legislative directors, we finally secured our second cosponsor.

While this process was time-consuming, it was not surprising. Working across the aisle, while touted as beneficial, can be risky. Bipartisan proposals need to be closely vetted to ensure that they reflect the senator's position and also do not undercut the work of the senator's copartisans. Before leading a bipartisan initiative, staff considers why no one else from the party has broached this issue. Would working on this topic infringe on a fellow copartisan's turf? Or has a member from our party offered a different alternative to this issue that the bipartisan version would undermine?

These, and other considerations, make working in a bipartisan manner both timand resource-intensive. Yet, in my experience, many senators seek to work with the other party whenever possible. While they are not always successful, senators' bipartisan inclinations ensure staffers invest substantial effort in at least approaching the opposition with their proposal, even if these efforts are fruitless.

\section{CONCLUSION}

Without question, congressional staffers have always worked in a hectic work environment.
Yet the 115th Congress's unusually frenetic pace, even during an abnormally dysfunctional period of unified government, reflects the changing nature of staff's day-to-day workload. Senators, and by extension their staff, still seek to write good public policy. Yet the hyper-partisan nature of the contemporary Congress requires staff members to work especially hard to craft enactable, bipartisan legislation.

Moreover, while partisan messaging has always been a feature of the US Congress, long-tenured staff regularly mentioned that it is more common than in the past. These factors, combined with the constant stream of unexpected controversies arising from the executive branch, conspired to generate a crushing workload on Capitol Hill. Indeed, a common conversation on Friday afternoons involved colleagues reminiscing about some controversy long in our collective rearview mirrors. Invariably, one of us would remind the group that the controversy happened on Tuesday.

\section{NOTE S}

1. DeSilver (2017) notes that by September 1, Congress had passed 46 non-ceremonial bills, which was the most since 2007 . However, $30 \%$ of these bills were Congressional Review Act resolutions. Among the other 32 bills, the most important were the spending continuing resolution in April, the sanctions bill, and a bipartisan bill that enacted new veterans affairs reforms. None were the landmark proposals offered by congressional Republicans and President Trump at the outset of the term.

2. Since making this speech, congressional Republicans enacted their sweeping tax cut bill.

\section{R E F E R E N C E S}

Desilver, Drew. 2017. “Congressional Productivity Is Up-But Many New Laws Overturn Obama-Era Rules." Pew Research Center: Fact Tank. http:// www.pewresearch.org/fact-tank/2017/08/29/115thcongress-productivity.

Gelman, Jeremy. 2017. "Reward Dysfunction: Interest Groups and Intended Legislative Failure." Legislative Studies Quarterly 42(4): 661-692.

Kaplan, Thomas and Robert Pear. 2017. "Senate Democrats Try to Gum Up Works Over Affordable Care Act Repeal." New York Times. https:/www. nytimes.com/2017/06/19/us/politics/health-caresenate.html

Lee, Frances. 2016. Insecure Majorities: Congress and the Perpetual Campaign. Chicago, Illinois: University of Chicago Press.

McCain, John. 2017. "Role of the Senate." United States Congressional Record: Vol. 153, No. 125 (July 25, 2017). https://www.congress.gov/congressionalrecord/2017/7/25/senate-section/article/s4168-2.

Uhrmacher, Kevin and Kevin Schaul. 2017. "At August Recess, Trump Remains Behind on Confirmations." Washington Post. https://www. washingtonpost.com/graphics/2017/politics/slowpace-of-trump-confirmations 